University Publications and Booksellers Box 29

Stellenbosch.

Witwatersrand University Press

Milner Park

Johannesburg.

Southwest Africa

M. Callesen

Windhoek.

Finnish Mission Press

Onupa, P. O.

Ondangua.

Sudan

American Mission Bookshop

Malakal.

C. M.S. Bookshop

Juba.

Senouhi (for Sudan)

54, Abdel Khalek Sarwat St.

Cairo.

Sudan Bookshop

P. O. Box 156

Khartoum.

Swaziland

Shieley Memorial Press

Box 14

Bremersdorp.

Tanganyika

Christian Bookshop

Mbeya.
C. M.S. Bookshop

P. O. Box 40

Dodoma, Moshi.

Dar-es-Salaam Bookshop

P. O. Box 237

Dar-es-Salaam.

S. P. C. K. Bookshop

P. O. Box 56

Lindi.

Tanganyika Standard Books

Department Box 33

Dar-es-Salaam.

Tunisia

Librairie M. Clerre (for Tunisia)

37 Rue Michelet

Algiers.

Uganda

Uganda Books hop

P. O. Box 145

Kampala.

University Bookshop

Makerere College

Box 262

Kampala

Upper Volta

Imprimerie Protestante

B. P. Ouagadougou。

Zanzibar

The Cathedral Bookshop

P. O. Box 770

Zanzibar.

\title{
News and Queries
}

German War Aims in Africa, 1914-18

Africa specialists will be interested in a recent publication about German policies during World War I, Fritz Fischer, Griff nach der Weltmacht: die Kriegszielpolitik des kaiserlichen Deutschland 1914-18 (Dusseldorf: Droste Verlag, [1961].896 p.). Mr. Fischer's most thorough study is based on archival research in both East and West Germany. 
The German colonial plans were formulated in August and September of 1914 by Wilhelm Solf, state secretary of the colonial office, and incorporated in the Imperial Chancellor's annexation program. Solf called for a German empire in central Africa which would include, aside from the existing German colonies, the French and Belgian Congo, Dahomey and Upper Volta, French Equatorial Africa, Angola, and the northern part of Mozambique. Other demands made in 1916 called for British Somaliland and the Madeira Islands. In late 1916 and 1917 the German admiralty presented its own ideas about territorial claims in Africa; these would include Dakar and its hinterland, Nigeria and Madagascar. Still not satisfied, in 1918 the Germans proposed the annexation of French and Portuguese Guinea, Gambia, Kenya, Uganda, and Northern Rhodesia.

E. Presseisen

Hoover Institution

Archives of the Mission of the Karuzi (Urundi)

The Archives of the Mission of the Karuzi (Urundi), Volume I (Physiography and Pedology, Phytosociology, and Ecoclimatology, and Hydrology) and Volume II (Maps of the Karuzi Basin-Soils and Vegetation) have been published in French by the Publications Service of the Technical Assistance Division, Ministry of Foreign Affairs and Exterior Commerce, 7, Place Royale, Brussels, Belgium.

From 1957 to 1960 a group of Belgian technicians conducted a study of water resources in Ruanda-Urundi as an aid to the authorities responsible for the economic development of this Belgian Trust Territory. The mission assembled a series of highly technical reports focusing on the Karuzi basin and its hydrology and hydrogeology. Furnished with charts, photographs, and excellent detailed maps, the reports provide the technical basis for overcoming one of the essential causes of poverty in this overpopulated region: inadequate knowledge of and control over water resources.

The Padmore Research Library on African Affairs

The Padmore Research Library, Accra, was established in June 1961 with the object of promoting African Studies in Ghana. It is dedicated to the memory of the late George Padmore, who had carried out considerable research into the life and struggles of African peoples.

The Library's holdings are strongest in materials concerning current political, social, and economic questions, but it also has collections of older historical, cultural, anthropological, and sociological works to provide the necessary background for research purposes. The stock includes books, periodicals, newspapers, microrecords, and other relevant material.

\section{Asia, Africa, and Latin America in Soviet Periodicals}

Soviet Periodical Abstracts, Asia, Africa and Latin America, is a quarterly publication of abstracts from Soviet scholarly journals. It serves as a guide to Soviet sources and a survey of Soviet studies on social and political developments in these areas. The abstracts are unique as an English-language review of Soviet material on Africa, material which is growing rapidly in volume and importance. Over 30 journals are systematically covered, including a number of periodicals seldom seen or reviewed in this country. Items available in translation in the Current Digest of the Soviet Press or from the Joint Publications Research Service are indicated accordingly. 
Subscription prices are $\$ 6.00$ a year for individuals and libraries with book funds under $\$ 10,000$, and $\$ 8.00$ a year for all others. Translations are prepared on request. For subscriptions and information, write the Slavic Languages Research Institute, Inc., l Seymour Place, White Plains, New York.

A sample abstract from the October 1962 issue (Volume II, No. 2) is given below.

Sharevskaia, B. I. "On the Character of the Power of the Chiefs Among Peoples of Tropical Africa in the Precolonial Period." SovEtnog, No. 1, Jan. -Feb. 1962, 67-70. Another discusision of the article by A.S. Orlova, "On the Place and Role of Traditional Powers of African Society in the Past and Present" (from SovEtnog, No. 6, 1960). The author disputes Orlova's view that societies led by strong leaders were early characteristic of certain areas of tropical Africa. The distinction between tribal society and state means the division of society into classes, and without a clear picture of the formation of classes in tropical Africa it is not possible to understand the Africans' present path of development. Bourgeois authors are unaware of the se distinctions, whereas Marxist researchers are armed with superior methodology. [See Asia, Africa and Latin America, Vol. I, No. 1, p. 19, and Vol. II, No. 1, p. 25, for other references to the Orlova article. See also below, No. 394.]

\title{
$\underline{\text { Joint Acquisitions List of Africana (JALA) }}$
}

Joint Acquisitions List of Africana is being issued in response to a recommendation made by the Joint Committee on African Resources, a subcommittee of the Association of Research Libraries' Farmington Plan Committee and the African Studies Association.

Publication is being supported by a special contribution from the Program of African Studies and the Center for Social Science Research at Northwestern University, under grants from the Ford Foundation. The main contributors are:

\author{
Boston University Northwestern University \\ Howard University Stanford University and the \\ Hoover Institution \\ Michigan State University University of California at Los Angeles
}

The New York Public Library

The Library of Congress

The United Nations Library in New York

Besides the United Nations, the only other non-American contributor is Cambridge University. We hope that in the future a selective number of libraries in Africa will contribute to this list regarding local acquisitions for which there would be more than local interest. Contributions from libraries and other such institutions are welcome as long as they reach us on $3 \times 5$ cards that can be alphabetized and photographed. We are not eager to receive additional notification for North American and European trade publications. We are, however, interested in both trade and other material from the rest of the world.

The material is not confined to printed and mimeographed media, but notification of arrival of phonograph records, maps, etc., are most welcome. The list is essentially a current one and items for it should have been issued within the last five years, and preferably the current year. 
Entries should be sent to the African Department, Northwestern University, Evanston, Illinois

Subscription orders, at $\$ 3.50$ per year $(6$ issues), should be sent to the above address.

The Booksellers and Stationers Association of Nigeria

On July 28, 1962, the Booksellers and Stationers Association of Nigeria was formed at Ibadan. In a plenary meeting articles of association, by-laws, and a declaration of aims were adopted; Mr. S. O. Oduntan, an Ibadan bookseller, was elected president of the Association. A formal request for registration and incorporation has been submitted to the Nigerian government and approval is expected in the near future.

The aims of the Association are to regulate the retailing of books and stationery and to provide a central organization through which to negotiate trade terms and distribution with publishers and suppliers. This marks a major step forward in Nigerian business practices.

Thus far, 63 paying members have been enrolled and at least 10 additional applications for membership have been received and are pending action by the membership committee. Once the C.M.S. (Church Missionary Society) Bookshops--the largest single book retailer in Nigeria with over 20 shops in the Western Region alone--decided to join the Association, several other large foreign-managed firms such as the Nigerian Baptist Book Stores and the S. I. M. (Sudan Interior Mission) Bookshops followed suit.

United States and Canadian Publications on Africa

The Africa Section of the Hoover Institution has recently agreed to assume responsibility for the annual publication of United States and Canadian Publications on Africa. The Africana Section of the Library of Congress published the first such compilation in 1962.

An attempt will be made to include all books and pamphlets on Africa south of the Sahara published in the United States and Canada during each calendar year. To ensure inclusion in the list, publishers and authors should send copies of books or reprints of articles to the Editor, United States and Canadian Publications on Africa, Hoover Institution, Stanford, California, U. S. A. Subscriptions will be offered at $\$ 3.50$ a year. Orders may be placed through the Publication Department, Hoover Institution, Stanford, California.

\section{Information Needed}

The Editors of the Africana Newsletter would like to receive communications from archives and libraries about their holdings and manuscript collections and from Institutes and schools about their research and teaching programs. Information on guides, calendars, and registers is also needed. 